\title{
Uniting the Balkans: Common Desires and \\ First Initiatives in the Interwar Period
}

\author{
Roumiana PRESHLENOVA
}

\begin{abstract}
The political and intellectual atmosphere in Europe after World War I, on the one hand, and the impact of the Great Depression on the agrarian states in the Balkans, on the other, fuelled the desire to search for solutions to common problems. The concern to unify winners and defeated in the war and to offer better prospects for economic development of the region led to the Balkan Conferences (1930-1933) and the Balkan Entente (1934) as their aftermath. Inner regional and European motives, promoters and mechanisms of the rapprochement between the Balkan peoples and its limits are outlined, along with the ineffectiveness of the integration plans and their institutionalization.
\end{abstract}

Keywords: Balkans, integration, Balkan Conferences, Balkan Entente, interwar period

Ideas about integration in the Balkans have a fairly rich tradition. The era of nationalism in the long $19^{\text {th }}$ century bore numerous plans of establishing a federation to succeed the Ottoman and the Habsburg Empires. These projects were elaborated mainly by intellectuals involved in revolutionary movements such as the Greek pioneer Rigas Fereos Velestinlis in the 1790s, and since the 1860s, the Bulgarians Georgi Rakovski, Liuben Karavelov, Hristo Botev; Svetozar Marković in Serbia; Ion Ghika, Ion Brătianu and Nicolae Bălcescu in Romania. Partisans of a Balkan Federation were also the revolutionary leaders Lajos Kossuth, Giuseppe Garibaldi and Giuseppe Mazzini. Unification should not only promote the entire development of the region but also fulfil the motto "The Balkans to the Balkan peoples", a common desire of almost all political leaders in the region. Later on, prominent "external" politicians interested in Balkan affairs like Bernhard von Bülow, Agenor Gołuchowski, Tommaso Tittoni and Alexander Iswolski regarded it as a means to surmount rivalry between the nascent Balkan nations.

In the $20^{\text {th }}$ century, one can retrace a dozen well documented negotiations on projects for Balkan integration beyond bilateral agreements. ${ }^{1}$ Surprisingly, Romania participated in most of them, although the attribute "Balkan" is neither relevant from the point of view of some present day Western historians nor acceptable for

1 The most important attempts at and agreements on Balkan integration in the 20th century are summarized in Roumiana Preshlenova, "Der Balkan: Bilanz misslungener Annäherungsversuche", in Michael Daxner, Peter Jordan, Paul Leifer, Klaus Roth und Elisabeth Vyslonzil (Eds.), Bilanz Balkan, Wien: Verlag für Geschichte und Politik, Wien, München: Oldenbourg Wissenschaftsverlag, 2005, pp. 24-46. For an overview up to World War II see also Loukianos Hassiotis, "The Ideal of Balkan Unity from a European Perspective (1789-1945)", Balcanica, 41, 2010, pp. 209-229. 
this country according to many Romanian scholars. Parallel to the attempts of agrarians, socialists and communists to include the federation movement in their programs for social reforms, the new trend took shape also among neoliberals in Europe. The latter regarded the federation as a desirable alternative for socialist international planning. ${ }^{2}$

In the Balkans as well, liberal politicians and intellectuals sought to induce the Balkan governments to overcome their controversies, to establish closer cultural, economic and political relations, and eventually to unite within a federal framework. An early manifestation of this strive, for example, was the daily journal entitled Balkanski Zgovor [Balkan Entente], whose first issue appeared in Sofia on July 28, 1915. The aim of its editor, Dimităr Mishev³, was to promote rapprochement among the Balkan states, and political leaders contributed with various articles in support of this goal. At this time, a similar idea was also launched by Winston Churchill. In the autumn of 1914, after the outbreak of the First World War, he sent the Roden Buxton brothers, Noel and Charles, activists of the Balkan Committee in London ${ }^{4}$, on a semi-official mission to Bulgaria with very indicative instructions: "The creation of a Balkan Confederation comprising Bulgaria, Serbia, Romania, Montenegro and Greece, strong enough to play an effective part in the destinies of Europe, must be the common dream of all their peoples.... I want you to make your friends in Greece and Bulgaria realize the brilliant but fleeting opportunity which now presents itself, and to assure them that England's might and perseverance will not be withheld from any righteous effort to secure the strength and union of the Balkan peoples". ${ }^{5}$ The choice the different Balkan states made to fight on different sides of the front line prevented the fulfilment of this idea.

The war divided the Balkans and Europe as a whole into winners and defeated who had to live together and trade with one another again. The concern of how to overcome the division reflected a common desire for a better future. A newspaper

2 On the neoliberal concepts of integration after the First World War, see Milène Wegmann, „Neoliberale Europa-Föderations konzepte 1918-1945“, in Journal of European Integration History, Number 1, Volume 8, 2002, pp. 11-35.

3 Later on, he published a survey on this issue, D[imităr] Mishev, Boris P. Petkov, La fédération balkanique, origine, développement et perspectives actuelles, Sofia: [s. n.], 1930.

4 On their mission, see Noel \& Charles Buxton, Missiyana Balkanite, Ivan Ilchev (ed.), Sofia: Universitetsko Izdatelstvo Kliment Ohridski, 1987. As a result of it, a book was published according to which the Balkan rapprochement was to be imposed from outside, by the Triple Entente. See Noel Buxton and Charles Roden Buxton, The War and the Balkans, London: George Allen \& Unwin Ltd., 1915. On the Balkan Committee in London (1903-1946) see Leften S. Stavrianos, “The Balkan Committee”, in Queen's Quarterly, XLVIII (Autumn) 1941, pp. 258-267.

5 Noel Buxton, C. Leonard Leese, Balkan Problems and European Peace, London: George Allen \& Unwin Ltd., 1919, pp. 71-72. 
campaign in favour of a Balkan customs union began in 1926 by C. Georgević. In 1928, he even organized the "Inter-Balkan Association for Peace and Prosperity". In June 1929, this group sent to the principal journals and statesmen of the Balkan and Western European countries a statement urging the creation of a Balkan customs union which would lead to political rapprochement and would be economically advantageous for the Balkans and the rest of Europe. Neither the governments nor the general public showed any appreciable interest in the plan. As a result of the influence of the leaders of the agrarian parties Stjepan Radic and Alexandar Stamboliyski, a number of societies for the furtherance of Yugoslav unity were organized in Belgrade, Prague, Vienna, Berlin, Munich, Paris, Geneva, Toulouse, Leipzig and other centres. In January 1930, these various groups combined to form the "League for the Rapprochement of the Serbs and Bulgarians and for the Union of all the South Slavs". ${ }^{6}$ The intellectual desire to unify the Balkan states developed parallel to the recovering of the official political relations between them. In 1929-1930, this was achieved on a bilateral base between Yugoslavia and Greece, Yugoslavia and Bulgaria, Greece and Turkey. On this occasion, Leften S. Stavrianos stated that "the Balkan situation was more settled at the end of 1929 than at any other time in the post-war period". ' In addition, most of the Balkan states concluded bilateral commercial treaties among them in 1926-1930. ${ }^{8}$

This retrieval of bilateral relations in the region was combined with the impact of the Great Depression. Comprised of predominantly agrarian states, the Balkans experienced a decrease in the prize of their main exports on international markets. The price of cereals dropped by about 50\% (which hit Yugoslavia, Romania and Bulgaria), of Mediterranean products (olives, olive oil, raisins, dried figs) by nearly $20 \%$ and of tobacco by $15 \%$. An agrarian block of eight East European states, including Yugoslavia, Romania and Bulgaria, assumed amid its two conferences in August and October 1930 in Warsaw and Bucharest, respectively, that the efforts of individual nations are no longer adequate for coping with such a situation and that common action was necessary. ${ }^{9}$

A third trend that gave impetus to positive developments in the Balkans was the idea of European unification which got stronger during and after World War I. It started in this period from Friedrich Naumann, with his Mitteleuropa (1915), continued with Tomas Masaryk, with his New Europe, and the establishment of the League of Nations as a supranational organization to protect the liberty of all

6 Leften S. Stavrianos, Balkan Federation. A History of the Movement toward Balkan Unity in modern times, Smith College Studies in History, vol. XXVII, Northampton, Mass., 1944, pp. 224-225.

7 Ibidem, pp. 224-229.

8 Robert J. Kerner, Harry N. Howard, The Balkan Conferences and the Balkan Entente 19301935, Westport, Connecticut: Greenwood Press Publishers, 1970, p. 22.

9 Leften S. Stavrianos, Balkan Federation, pp. 229-230. 
nations and secure world peace on the initiative of Woodrow Wilson at the Paris Peace Conference in 1919. Unification plans were further launched by Richard Nikolaus von Coudenhove-Kalergi, with his Paneuropean Union (1923), and culminated in Aristide Briand's proposal for the United States of Europe in 1929. ${ }^{10}$ They were all based on the French-German political understanding and economic co-operation with Aristide Briand and Gustav Stresemann as their personification, who received the Nobel Peace Prize for this initiative in 1926. In 1919-1939, no fewer than 600 books and articles in journals on the idea of European unification were published, most of them in French and German, not including texts in the daily press. ${ }^{11}$ Briand's initiative found supporters among politicians and intellectuals in all Balkan countries, and Coudenhove-Kalergi gave a public lecture at the Bulgarian Academy of Sciences in Sofia on March $25^{\text {th }} 1926 .{ }^{12}$ All these ideas were reflected in the press or in particular books in the Balkans. Thus, the strive for Balkan integration emerged concurrently with similar initiatives for economic and political unions at a European level and was maybe inspired by them.

Former Greek prime-minister Alexander Papanastassiou used the 1929 meeting of the XXVII Universal Congress of Peace in Athens to gain support for the establishment of an institution for Balkan rapprochement in economic, social, intellectual and political terms, in the hope of achieving a Balkan union. He believed that, despite the different languages, Balkan peoples had common economic interests and shared history, culture and traditions, and that the republican reforms in Turkey since the 1920s would make Balkan unification possible. In the resolution of the congress on this issue it was stated that: "The Conference considers that a union among the Balkan peoples is most opportune, and for this purpose special Balkan Conferences should be organized annually". ${ }^{13}$

The International Bureau of Peace in Geneva invited the six foreign ministers of the Balkan states - Albania, Bulgaria, Greece, Romania, Turkey and Yugoslavia, in May 1930, to a Balkan Conference to be held in Athens. All governments had expressed their willingness to send delegates. In the preparatory work, 23 memoranda altogether from Greek, Yugoslav, Romanian, and Bulgarian scholars, politicians, and experts were submitted. They considered all major aspects of economy, culture and social life. It was felt that the process of fusion would be longer,

10 Peter Bugge, "The nation supreme. The idea of Europe 1914-1945", in Kevin Wilson, Janvander Dussen (eds.), The History o fthe Idea of Europe, London and New York: Routledge, 1995, pp. 83-106.

11 Wolfgang Schmale, Geschichte Europas, Wien-Köln-Weimar: Böhlau Verlag, 2000.

12 Konstantin Manchev, "Ideyata za Panevropa", in Otets Paisiy, X, 4, 1937, p. 124. See also Konstantin Manchev, Panevropa i balkanskata federatsiya (idei i realizatsiya), Lom 1932; Constantin Svolopoulos, L'attitude de la Grèce vis-à-vis du project Briand 'D'Union fédérale de l'Europe“, in Balkan Studies, Vol. 29, Nr. 1, 1988, pp. 29-38.

13 Robert J. Kerner, Harry N. Howard, op. cit., p. 173. 
starting with preliminary technical and economic agreements, followed by the formation of a customs agreement, and finally the creation of the federation of Balkan states. ${ }^{14}$

The best description of the Balkan Conference is that by Al. Papanastassiou: "Though based on the national groups, composed of politicians, representatives of peace organizations, universities, and professional organizations, and though its decisions do not obligate the governments, this organization has nevertheless an official character, not only because the governments of the six countries support the activities of the national groups, but also because the delegations of each country to the Conferences are chosen after consultation with the government, and these governments are represented at each Conference by their diplomatic officials (who follow the deliberations in the capacity of observers) in the country in which the Conference meets". 15

The first Balkan Conference took place in Athens on $5^{\text {th }}-12^{\text {th }}$ October 1930, as a semi-official gathering of about 150 delegates, experts, and observers. Prominent politicians attended the event: the president of the Romanian Chamber of Deputies, the vice-president of the Turkish National Assembly, senators, deputies, the diplomatic corps in Athens, representatives of the League of Nations Secretariat, the International Labour Office, the International Peace Bureau, the Inter-parliamentary Union, the Carnegie Endowment for International Peace and other international organizations. The opening was organized as a great festivity. A Balkan flag with six golden stars and six stripes of white, blue, green, yellow, red, and white symbolized the future union, and a band played the "Balkan Hymn of Peace", composed specifically for the auspicious event. The Balkan Olympic Games brought the youth of the peninsula together. It seemed that a new epoch in Balkan history was about to begin. In his welcoming address, Papanastassiou expressed the common inspiration: "The achievement of our ideal will mark a new era of prosperity and progress... Today, by our attitude in the Conference and by its continuation, we prove that we, the Balkan peoples, are to become the masters of our destinies and are to develop again in this corner of Europe a new and glorious civilization which will illuminate the world". ${ }^{16}$ Later on, Mustafa Kemal Attaturk expressed similar optimism and enthusiasm when addressing the works of the conference in Turkey. ${ }^{17}$ The proceedings and/or many of the official documents were published in Première Conférénce balkanique. Documents

14 Ibidem, pp. 26-29. The concept of Rainer Santi about the First Balkan Conference in Athens in 1930 is that it was „Defusing the European powder-keg” (,die Entschärfung des europäischen Pulverfasses“). Rainer Santi, 100 Jahre Friedensarbeit. http://www.santibox. ch/Peace/Friedensarbeit.html\#Entschärfung. Accessed May $10^{\text {th }} 2013$.

15 Cited after Leften S. Stavrianos, Balkan Federation, p. 231.

16 Cited after Robert J. Kerner, Harry N. Howard, op. cit., p. 31.

17 Les Balkans, 1931, No. 13-14, p. 1. 
officiels (Athens 1931), II Conférénce balkanique. Documents officiels (Istanbul 1932), III Conférénce balkanique. Documents officiels (Bucharest 1932), IV Conférénce balkanique.Documents officiels (Athens 1934) and in the journal Les Balkans, founded in 1930 by A. Papanastassiou jointly with M. X. Lefcoparidis and financed mainly by the Carnegie Endowment for International Peace. ${ }^{18}$

Four annual conferences were held altogether, as follows: the first in Athens, October $5^{\text {th }}-12^{\text {th }}, 1930$; the second in Istanbul and Ankara, October $19^{\text {th }}-26^{\text {th }}, 1931$; the third in Bucharest, October $22^{\text {nd }}-27^{\text {th }}$, 1932; the fourth in Salonica, November $5^{\text {th }}-11^{\text {th }}, 1933 .{ }^{19}$ It is impossible to present their work within a limited publication. ${ }^{20}$ An overview could just summarize their results, rather than present a detailed factual account.

Six particular commissions had been appointed to study the various aspects of regional unification. They were chaired by representatives of each Balkan country. The Commission on Organization prepared the statutes and the rules of the Balkan Conference.

The Commission on Economic Affairs studied in detail the economic position of every Balkan country and of the peninsula as a whole. It proposed measures for their improvement and for Balkan co-operation. The general aim was to protect agriculture and industry in the Balkans, as well as to adopt a concerted commercial policy, to promote collaboration between banks, and to investigate the possibility of a monetary union. Some specific projects were also discussed, for example the establishment of the Balkan Chamber of Commerce and Industry patterned after the International Chamber of Commerce. It was officially opened in Istanbul, in May 1932.

The weak basis for economic co-operation of the Balkan states, however, is evident even from the data reflecting their mutual trade. While trade with the neighbours accounted for about half of the overall commodity turnover in Central and Western Europe, in the Balkans it remained insignificant for all countries.

18 For a full account of all memoranda submitted by members of the particular national delegations, see Robert J. Kerner, Harry N. Howard, op. cit., pp. 245-257.

19 The dates of the conferences vary in the different sources. Here they are as given in Alexanderos Papanastassiou, Vers l'union balkanique: les conférences balkaniques: Athènes: 5-12 Oct. 1930: Istanbul et Ankara: 19-26 Oct. 1931: Bucarest: 22-27 Oct. 1932: Salonique: 5-11 Nov. 1933. Paris: Conciliation Internationale, [1934].

20 The work of the Balkan Conferences is retraced in detail in Theodore Ivanoff Geshkoff, Balkan union: a road to peace in Southeastern Europe, New York: Columbia University Press, 1940; Robert J. Kerner, Harry N. Howard, op. cit.; Norman J. Padelford, Peace in the Balkans. The Movement Towards International Organization in the Balkans, New York: Oxford University Press, 1935. A first German reaction see in Hermann Gross, Grundlagen und Ziele der Balkankonferenz, Leipzig: C. Heymann, 1932. 
Balkan Trade as Share of the Overall Foreign Trade of the Various Balkan States ${ }^{21}$

\begin{tabular}{|l|l|l|l|l|}
\hline & \multicolumn{2}{|l|}{$1926-1929$} & $1931-1938$ & \\
\cline { 2 - 5 } & Imports & Exports & Imports & Exports \\
\hline Albania & 14 & 26 & - & - \\
\hline Bulgaria & 11 & 16 & 6 & 2 \\
\hline Greece & 19 & 3 & 14 & 5 \\
\hline Romania & 2 & 9 & 3 & 6 \\
\hline Turkey & 5 & 8 & 2 & 5 \\
\hline Yugoslavia & 5 & 10 & 4 & 5 \\
\hline
\end{tabular}

The Commission on Communications accounted that direct connections between the Balkan states were still undeveloped and not a single bridge spanned the Danube. The first conference adopted resolutions for the construction of direct rail, air, road, and telegraphic lines between all the capitals and of two main trunk lines (rail and road) from the Black Sea to the Adriatic and from the Danube to the Aegean. It approved a convention for a Balkan Postal Union to reduce postal rates between the Balkan countries and to improve postal service in the region. This convention was partially applied.

The Commission on Intellectual Cooperation adopted a program, calling for exchange of university students, professors, and intellectual associations; instruction in a Balkan language other than that of the national state in all universities; teaching history as an aid to union; translation of Balkan folklore into the various Balkan languages; and the celebration of a Balkan Week in each country at a fixed date. A Balkan Institute for Intellectual Cooperation with a women's section was approved. A Permanent Commission of Balkan Jurists was established to harmonize the law of the particular states.

The Commission on Social Policy urged that serious attention be given to the precarious plight of the agricultural and industrial workers, pointing out that their support was a prerequisite for success. Resolutions were adopted in favour of the improvement and collaboration of sanitary services, abolition of child labour and prostitution, equal treatment of foreign workers, and ratification of the conventions and recommendations adopted by the International Labour Office.

From this overview it is evident that, in the fields of intellectual cooperation, social policies, communications and economic relations, a number of constructive projects were adopted, and a few of them were put into operation. In political questions, however, the situation was quite different.

The Commission on Political Relations faced the task of reconciling conflicting interests. The Bulgarian delegation insisted on including the problem of minorities

21 Estimated from data in Vera Katsarkova, Ikonomicheskite otnosheniya na Bălgariya $s$ balkanskite dărzhavi mezhdu dvete svetovni voyni (1919-1941), Sofia: Bălgarska akademiya na naukite, 1989, pp. 181, 231, 241-2. 
in the agenda of the conference. After World War I, the country had to yield territories to all neighbours - altogether $11,000 \mathrm{~km}^{2}$ populated by Bulgarians. ${ }^{22}$ About 600,000 of them left these territories and fled to Bulgaria. Next to reparations and contributions, this refugee influx created a serious economic and social problem for the government. Many ethnic Bulgarians remained in the lost territories, becoming a minority. Papanastassiou conceded that the minority issue might be regarded "in principle". A general discussion on minorities took place, but since the fundamental questions at hand had already been ruled out, the debate was limited and inconclusive. On the other hand, the Yugoslav representatives at the second Balkan Conference in Istanbul underlined as an obstacle for political understanding the involvement in other states' affairs (Bulgarian support for the irredentist Internal Macedonian Revolutionary Organization, IMRO, in the Yugoslav part of Macedonia was inferred) and the alliance of Balkan states with external powers (in this case Albania's treaties providing for friendship and alliance with Italy were envisaged). Nevertheless, the commission adopted a resolution recommending that the Balkan foreign ministers meet annually to discuss outstanding questions; that the council appoint a committee to undertake the study of a Balkan pact involving outlawry of war, amicable settlement of all disputes, and mutual assistance. The proposed pact was modelled after the Little Entente's General Act of Conciliation, Arbitration and Judicial Settlement. The conference further recommended that, pending the elaboration of the pact, an attempt should be made to dispose of the contentious minorities question by direct, bilateral negotiations between the national groups. Consequently, the Bulgarian delegation at the third conference in Bucharest proposed the adjournment of the debate on a Balkan Pact until the next conference, in order to arrange bilateral negotiations on the minorities' question. With the rejection of this proposal the Bulgarian delegates left the conference. ${ }^{23}$

In their absence, the delegates of the other five countries approved The Draft Balkan Pact of the Balkan Conference. It envisaged non-aggression, friendship, peaceful settlement of conflicts and mutual assistance. In addition, this draft included proposals for dealing with the minorities problem, which provided that each contracting party should establish an Office of Minorities to collect

22 It is impossible within the limits of this publication even to cite the huge amount of publications on the minorities issue in the Balkans. A recent publication on this matter is Dušan T. Bataković (ed.), Minorities in the Balkans: state policy and interethnic relations: (1804-2004), Belgrade: Balkanološki institut SANU, Special editions 111, 2011.

23 On the Bulgarian position see Georgi P. Genov, La Bulgarie et les conférences balkaniques, Sofia, Impr. "La Bulgarie", 1931. D. Mishev had emphasized earlier that a Balkan Federation which would leave millions of people as minorities without national and human rights would be a parody of the great idea, that those who would be against the prior application of the treaties concerning the minorities would be against peace and the Balkan federation. D[imitar] Mishev, Boris P. Petkov, op. cit., p. 35. 
petitions on the application of the treaties concerning minorities, and that a Balkan Commission of Minorities representing the six Balkan countries should meet once a year in turn, to examine complaints from minorities. Any question on which the members of the Commission failed to agree would be referred to the League of Nations. This pact represents the most important achievement of the conferences in the political field. The fourth conference at Salonica expressed the hope that the governments would adopt the draft Balkan Pact and arrange for annual meetings between their foreign ministers to smooth out disagreements. In reply, the Bulgarian delegation issued a declaration accepting the pact on condition that the equal status of Bulgaria would be recognized and the provisions regarding minorities would be loyally enforced.

Nevertheless, different diplomatic activities undermined the understanding achieved. Turkey, Yugoslavia and Romania signed non-aggression pacts with the Soviet Union in summer 1933. In the same year, a rapprochement between Bulgaria and Yugoslavia was reached (a protocol for measures against bands was signed and the royal families exchanged visits), Turkey and Greece concluded a treaty for mutual warranty of their common frontiers, for friendship, understanding and collaboration in protection of their common interests. Thus, the idea of Balkan integration was parcelled and replaced by a series of bilateral agreements.

At a meeting in Ankara, the foreign ministers of Romania, Yugoslavia, Greece and Turkey agreed on a Balkan Pact. The respective treaty was signed on February $9^{\text {th }} 1934$ in Athens, again with great festivities. It was patterned after the Little Entente of February 1933, which united Czechoslovakia, Romania and Yugoslavia, aiming to contain Hungarian revisionism. Some observers regarded the Balkan Entente as an extension of the Little Entente or as its parallel organization. ${ }^{24}$ The treaty provided mutual warranty for the existing frontiers in the Balkans. In addition, the particular members of the pact explicitly declared that its application would not involve any of them into hostilities with a Great Power. ${ }^{25}$ Thus, the pact was reduced to a pure anti-Bulgarian instrument. Not coincidentally, one spoke in Bulgaria about it as an "encircling". It was criticized by the Greek opposition headed by Eleftherios Venizelos as worthless, given the absence of Bulgaria. And the British ambassador to Athens stated in, a press communication on the very day of the conclusion of the pact, that every rapprochement and co-operation between the Balkan states would be welcome if it is not directed against any state in the region and if the accession of Bulgaria is guaranteed. ${ }^{26}$ Only in France, which

24 Hans Hartl, Der "einige” und "unabhängige” Balkan, München: R. OldenbourgVerlag, 1977, pp. 26, 37.

25 Four-Power Balkan Pact, of The Statute of Organization of the Balkan Entente and of The Statute of the Advisory Economic Council of the Balkan Entente are published in Robert J. Kerner, Harry N. Howard, op. cit., pp. 232-237.

26 Hans Hartl, op. cit., pp. 37-38. 
remained the patron and defender of the status quo in Southeastern Europe, was the treaty admired despite the fact that it divided the Balkan countries again in winners and losers. The conclusion of the Balkan Pact was the main reason to adjourn sine die the fifth Balkan Conference scheduled for early October 1934 in Istanbul. In fact, the delegations never met again.

The general political conjuncture at this time predetermined the further development of the Balkan rapprochement once again. The rise of Hitler to power and his bellicose statements regarding the Treaty of Versailles stimulated the revisionist movement throughout Europe. On the other hand, trade dependence of all Balkan states upon Nazi-Germany grew since mid 1930s: about $35 \%$ of their imports came from Germany and $27-50 \%$ of their exports went there. Furthermore, Germany, which had a trade deficit with them, did not liquidate its debt, except by exports. Admittedly, this economic hegemony combined with direct or indirect political repercussions additionally undermined Balkan understanding.

The Balkan Conferences were a promising but fragile beginning of a rapprochement between the Balkan states. In contrast to all previous plans for regional integration that were directed against a common enemy and thus were "anti" in their character $^{27}$, they were pro-Balkan and pro-European. They brought together a part of the Balkan elites and demonstrated that they were capable of mutual understanding. They are telling evidence that the idea of a Balkan federation was not limited only to left and leftist parties which issued in Vienna, Austria, and then in Frankfurt, Germany, their newspaper La Fédération balkanique from 1924 to 1932. ${ }^{28}$ The Balkan Conferences stimulated co-operation between non-governmental organizations in the region. Most successful and long-lasting were the established relations among the national medical associations, the unions of mathematicians and sportsmen. ${ }^{29}$

During the years of the Balkan Conferences, a number of newspapers and journals were printed in Bulgaria under the name Balkan [Balkan], Balkanski pregled [Balkan Review], Balkanski săyuz [Balkan Union], Balkansko sdruzhenie [Balkan Unification] etc. Besides, the Paris based edition Revue des Balkans was supplied. Many of them disseminated hope and great expectations, but sober evaluations were present, too. Repeatedly, the motive of turning the Balkans into a Great Power through their integration was stressed. The journal Balkani [Balkans] for instance wrote that the Balkan peoples had started understanding that their unification as a

27 See for example Henrik Batowski, "Le mouvement pan balkanique et les différents aspects des relations interbalkaniques dans le passé (Indications de méthode et aperçu des faits), in Revue internationale des Études balkaniques, vol. 6, 1938, pp. 320-343.

28 Vladimir Claude Fišera, "Communisme et intégration supranationale: la Revue „La Fédération balkanique" (1924-1932)", in Revue d'histoire moderne et contemporaine, T. 34e, No. 3, 1987, pp. 497-508.

29 Apostolos Hristakudis, Mnogostrannoto sătrudnichestvo v Yugoiztochna Evropa $i$ evropeyskata integratsiya. Istoriya i săvremennost, Sofia: Heron pres, 2002, pp. 22-26. 
federation with an area of 1,250.000 square miles or twice as much as France, and a population of 50 million, had to become the third most important [European] state after Russia and Germany. ${ }^{30}$

The Balkan Conferences outlined some important principles, first of all a General Resolution on the Balkan Union. Further, a number of practical goals were achieved: a Balkan Postal Convention; a Balkan Chamber of Commerce and Industry; a Balkan Press Association; a Balkan Tourist Federation; a Draft Balkan Pact; a Convention on the status of Balkan citizens; a draft of a Regional Economic Understanding; a Draft Statutes of the Balkan Parliamentary and Social Union. The Balkan Conferences did not bring progress and prosperity to the predominantly agrarian and underdeveloped region, nor did they launch a new civilization, as Papanastassiou pretended, but there were no military conflicts on the peninsula until the Second World War. In other words, the territorial status quo was being preserved until again external powers - Italy and Nazi-Germany - forced changes of borders and human distress in the region.

\section{Bibliography}

Bataković, Dušan T. (ed.), (2011), Minorities in the Balkans: state policy and interethnic relations (1804-2004), Beograd: Balkanološki institut SANU, Special editions 111.

Batowski, Henrik, (1938), "Le mouvement panbalkanique et les différents aspects des relations interbalkaniques dans le passé (Indications de méthode et aperçu des faits) ", in Revue internationale des Études balkaniques, vol. 6, 320-343.

Bugge, Peter, (1995), "The nation supreme. The idea of Europe 1914-1945”, in Wilson, Kevin and Dussen, Jan van der (ed.), The History of the Idea of Europe, London and New York: Routledge, 83-146.

Buxton, Noel and Charles Roden, (1915), The War and the Balkans, London: George Allen \& Unwin Ltd.

Buxton, Noel and C. Leonard Leese, (1919), Balkan Problems and European Peace, London: George Allen \& Unwin Ltd.

Buxton, Noel i Charles, (1987), Missiya na Balkanite, Ivan Ilchev (ed.), Sofia: Universitetsko Izdatelstvo Kliment Ohridski.

Fišera, Vladimir Claude, (1987), “Communisme et intégration supranationale: la Revue „La Fédération balkanique" (1924-1932) ", in Revue d'histoire moderne et contemporaine, T. 34e, No. 3, 497-508.

Genov, Georgi P. (1931), La Bulgarie et les conférences balkaniques, Sofia: Impr. La Bulgarie. Geshkoff, Theodore Ivanoff, (1940), Balkan union: a road to peace in Southeastern Europe, New York: Columbia University Press.

30 Cited after Milcho Lalkov, Ot nadezhda kăm razocharovanie. Ideyata za federatsiyata v Balkanskiya Yugoiztok (1944-1948), Sofia: IK „Vek 22“, 1994, p. 63. The Turkish newspaper Stambul (03.10.1931) estimated the population of a Balkan union even higher, at 57,450.000. See Hans Hartl, op. cit., p. 28. Other estimations fix the area at 600,000 square miles and the population at some 60,000.000, which exceeds that of France, Italy or Great Britain. See Robert J. Kerner, Harry N. Howard, op. cit., p. 23. 
Gross, Hermann, (1932), Grundlagen und Ziele der Balkankonferenz, Leipzig: C. Heymann. Hartl, Hans, (1977), Der "einige” und "unabhängige” Balkan, München: R. Oldenbourg Verlag. Hristakudis, Apostolos, (2002), Mnogostrannoto sătrudnichestvo v Yugoiztochna Evropa i evropeyskata integratsiya. Istoriya i săvremennost, Sofia: Heron pres.

Katsarkova, Vera, (1989), Ikonomicheskite otnosheniya na Bălgariya s balkanskite dărzhavi mezhdu dvete svetovni voyni (1919-1941), Sofia: Bălgarska akademiya na naukite.

Kerner, Robert J., Howard, Harry N., (1970), The Balkan Conferences and the Balkan Entente 1930-1935, Westport, Connecticut: Greenwood Press Publishers.

Lalkov, Milcho, (1994), Ot nadezhda kăm razocharovanie. Ideyata za federatsiyata $v$ Balkanskiya Yugoiztok (1944-1948), Sofia: IK ,Vek 22“.

Hassiotis, Loukianos, (2010), "The Ideal of Balkan Unity from a European Perspective (17891945)", Balcanica, 41, 209-229.

Manchev, Konstantin, (1932), Panevropa i balkanskata federatsiya (idei i realizatsiya), Lom.

Manchev, Konstantin, (1937), "Ideyata za Panevropa", in Otets Paisiy, X, 4, 121-125.

Mishev, D[imitar], Boris P. Petkov, (1930), La fédération balkanique, origine, développement et perspectives actuelles, Sofia: [s. n.].

Padelford, Norman J., (1935), Peace in the Balkans. The Movement towards International Organization in the Balkans, New York: Oxford University Press.

Papanastassiou, Alexanderos, [1934], Vers l'union balkanique: les conférences balkaniques: Athènes: 5-12 Oct. 1930: Istanbul et Ankara: 19-26 Oct. 1931: Bucarest: 22-27 Oct. 1932: Salonique: 5-11 Nov. 1933, Paris: Conciliation Internationale.

Preshlenova, Roumiana, (2005), „Der Balkan: Bilanz misslungener Annäherungsversuche“, in Michael Daxner, Peter Jordan, Paul Leifer, Klaus Roth und Elisabeth Vyslonzil (Hrsg.): Bilanz Balkan, Wien: Verlag für Geschichte und Politik, München: Oldenbourg Wissenschaftsverlag, 24-46.

Santi, Rainer, 100 Jahre Friedensarbeit. http:/www.santibox.ch/Peace/Friedensarbeit.ht$\mathrm{ml}$ \#Entschärfung. Accessed May $10^{\text {th }} 2013$.

Schmale, Wolfgang, (2000), Geschichte Europas, Wien-Köln-Weimar: Böhlau Verlag.

Stavrianos, Leften Stavros, (1941), "The Balkan Committee”, in Queen's Quarterly, XLVIII (Autumn), 258-267.

Stavrianos, Leften Stavros, (1944), Balkan Federation. A History of the Movement toward Balkan Unity in Modern Times, Smith College Studies in History, vol. XXVII, Northampton, Massachusetts.

Svolopoulos, Constantin, (1988), L'attitude de la Grèce vis-à-vis du project Briand "D'Union fédérale de l'Europe“, in Balkan Studies, Vol. 29, Nr. 1, 29-38.

Wegmann, Milène, (2002), „Neoliberale Europa-Föderationskonzepte 1918-1945“, in Journal of European Integration History, Number 1, Volume 8, 11-35. 